\title{
Increased eNO and pulmonary iNOS expression in eNOS null mice
}

\author{
S. Cook*,\#, P. Vollenweider*,\#, B. Ménard", M. Egli*,\#, P. Nicod*, U. Scherrer*,\#
}

Increased eNO and pulmonary iNOS expression in eNOS null mice. S. Cook, P. Vollenweider, B. Ménard, M. Egli, P. Nicod, U. Scherrer. C ERS Journals Ltd 2003. ABSTRACT: Nitric oxide (NO) is a major regulatory molecule of the cardiovascular system; however, measurement of vascular NO synthesis in vivo represents a major challenge. NO stemming from the lower respiratory tract has been used as a marker of vascular endothelial function. Experimental evidence for this concept is lacking. Therefore, the aim of the present study was to investigate this relationship.

Lower respiratory tract exhaled NO concentration, together with systemic and pulmonary artery pressure, was measured in endothelial nitric oxide synthase (NOS) (eNOS) null mice (eNOS-I-). Similar studies were performed in inducible NOS (iNOS) null mice (iNOS-I-).

Defective endothelial NO synthesis in eNOS-I- mice (evidenced by systemic and pulmonary hypertension) was associated with augmented exhaled NO levels $(12.5 \pm 1.9$ versus $9.8 \pm 1.2$ parts per billion (ppb), eNOS-I- versus wild type), whereas normal endothelial NO synthesis in iNOS-I- mice was associated with decreased exhaled NO levels (4.3 $\pm 1.5 \mathrm{ppb})$. Augmented exhaled NO levels in eNOS-I- mice were associated with upregulation of iNOS expression in the lung.

These results indicate that inducible nitric oxide synthase is a major determinant of gaseous nitric oxide production in the lung, and lower respiratory tract exhaled nitric oxide does not always represent a marker of vascular endothelial nitric oxide synthesis.

Eur Respir J 2003; 21: 770-773.
*Dept of Internal Medicine, and "Botnar Centre for Clinical Research, University Hospital, Lausanne, Switzerland.

Correspondence: U. Scherrer, Dept of Internal Medicine, BH 10.642, Centre Hospitalier Universitaire Vaudois, CH-1011 Lausanne, Switzerland.

Fax: 41213140451

E-mail: Urs.Scherrer@chuv.hospvd.ch

Keywords: Endothelial dysfunction, exhaled nitric oxide, nitric oxide synthase, nitrite/nitrate plasma concentration, pulmonary circulation, pulmonary hypertension

Received: December 272002

Accepted after revision: January 132003

This study was supported by grants from the Swiss National Science Foundation (Bern, Switzerland), International Olympic Committee (Lausanne, Switzerland), Emma Muschamp Foundation (Lausanne) and Placide Nicod Foundation (Lausanne)

This work was presented, in part, at the European Respiratory Society Annual Congress 2000, Florence, Italy, August 30-September 2, 2000, and at Experimental Biology 2001, Orlando, FL, USA, March 31-April 4, 2001.
Since the late 1980s, nitric oxide (NO) has emerged as a major regulator of the cardiovascular system [1]. Measurement of vascular endothelial nitric oxide synthase (NOS) (eNOS) activity and its final product $\mathrm{NO}$ in vivo still represents a major challenge, because the small amount of NO produced by the endothelium is rapidly scavenged by haemoglobin and then inactivated. To date, the contribution of NO to the regulation of vascular tone has been assessed by indirect methods, examining specific modifications of physiological responses induced by NOS inhibitors and NO donors, and/or measuring levels of NO metabolites or cyclic guanosine monophosphate [2].

NO is present in the exhaled air of many animal species and humans [3], but its origin and physiological function are incompletely understood. In the respiratory tract, all three NOS isoforms are expressed in tissues close to the airways. Although there is consensus that under normal conditions, a large proportion of the exhaled $\mathrm{NO}$ is synthesised by inducible NOS (iNOS) located in the epithelial cells of the upper respiratory tract $[4,5]$, the origin and function of lower respiratory tract exhaled NO is incompletely understood. It has been claimed that exhaled NO stemming from the lower respiratory tract represents a marker of vascular endothelial NO synthesis [6-12]. Experimental evidence for this concept is lacking, however, and studies in humans, using pharmacological NOS inhibitors, suggest that eNOS barely albeit significantly, contributes to lower respiratory tract exhaled NO concentration [13]. A potentially important limitation of these studies was that the available pharmacological NOS inhibitors were not selective for a specific NOS isoform. Therefore, the aim of the present study was to measure pulmonary exhaled NO levels together with plasma nitrite/ nitrate $(\mathrm{NOx})$ concentration and systolic pulmonary artery pressure in eNOS null (eNOS-/-) and wild-type mice. In order to gain further mechanistic insight, similar studies were performed in iNOS null (iNOS-/-) mice and pulmonary NOS isoform expression examined in eNOS-/- and wild-type mice.

\section{Methods}

Experiments were carried out under protocols approved by the Institutional Animal Care and Use Committee.

eNOS and iNOS knockout mice were generated as previously described [14, 15]. Knockout and control mice were generated by mating heterozygous animals from the authors' colony. Male 11-14-week-old litter mates (body weight $22-26 \mathrm{~g}$ ) were used in the experiments. Mice were housed in the authors' animal facility with free access to a low-nitrate diet (Indulab, Gams, Switzerland, $<32 \mathrm{mg} \cdot \mathrm{kg}^{-1}$ nitrate) and water. 


\section{Measurement of exhaled nitric oxide concentration}

Mice ( $\mathrm{n}=9$ per group) were anaesthetised (ketamine $100 \mu \mathrm{g}$. $\mathrm{kg}$ body weight ${ }^{-1}$ and xylazine $10 \mu \mathrm{g} \cdot \mathrm{kg}$ body weight ${ }^{-1}$, intraperitoneal), intubated and ventilated with NO-free $(<1$ parts per billion (ppb)) air (Harvard 55-7066 small animal ventilator; Harvard Apparatus, South Natick, MA, USA, respiratory frequency $150 \mathrm{breaths} \cdot \mathrm{min}^{-1}$; tidal volume $9 \mu \mathrm{L} \cdot \mathrm{g}$ body weight $\left.^{-1}\right)$. Body temperature was kept constant $\left(37 \pm 0.5^{\circ} \mathrm{C}\right)$ by a warming table. Exhaled air was collected by connecting a Mylar collecting bag to the tracheal tube for $10 \mathrm{~min}$. The samples were analysed within $10 \mathrm{~min}$ of collection using a chemiluminescence NO analyser (NOA 280; Sievers, Boulder, CO, USA) calibrated before each measurement against a NOfree gas and a reference gas containing 40 parts per million NO in pure nitrogen.

\section{Measurement of plasma nitritelnitrate concentration}

Immediately after exhaled NO sampling, $400 \mu \mathrm{L}$ blood was collected by heart puncture. Coagulation was prevented by adding $10 \mu \mathrm{L}$ heparin $\left(5,000 \mathrm{IU} / \mathrm{mL}^{-1}\right)$, and the sample centrifuged for $10 \mathrm{~min}$ at $1,650 \times \mathrm{g}$ at $4^{\circ} \mathrm{C}$. The supernatant was collected, frozen in liquid nitrogen and stored at $-80^{\circ} \mathrm{C}$ until use. NOx was measured using chemiluminescence after reduction of NOx to NO by vanadium chloride [16].

\section{Semiquantitative Western blotting}

The lungs and liver were removed and immediately frozen in liquid nitrogen. They were then homogenised in a buffer containing $50 \mathrm{mM}$ tris-(hydroxymethyl)-aminomethane (Tris)/ $\mathrm{HCl}(\mathrm{pH} 7.5), 150 \mathrm{mM}$ sodium chloride, $1 \%$ Nonidet P-40, $0.1 \%$ sodium dodecyl sulphate (SDS) and a cocktail of protease inhibitors (Complete ${ }^{\mathrm{TM}}$ Protease Inhibitor Cocktail Tablets; Boehringer, Ingelheim, Germany). Homogenates were centrifuged for $10 \mathrm{~min}$ at $3,000 \times g$ at $4{ }^{\circ} \mathrm{C}$. The supernatant was collected and centrifuged again for $10 \mathrm{~min}$ at $20,000 \times g$ at $4^{\circ} \mathrm{C}$. Proteins $(100 \mu \mathrm{g})$ were separated by SDSpolyacrylamide gel electrophoresis and transferred to nitrocellulose membranes (Hybond ECL; Amersham, Little Chalfont, UK) in $25 \mathrm{mM}$ Tris $/ 192 \mathrm{mM}$ glycine $/ 20 \%$ (volume/ volume) methanol buffer $(\mathrm{pH} \mathrm{8.0)}$. The membranes were blocked with $20 \mathrm{mM}$ Tris-buffered saline (137 mM) (pH 7.5) containing $5 \%$ (weight/volume) nonfat milk for $1 \mathrm{~h}$ at room temperature and then blotted with specific iNOS and neuronal NOS (nNOS) antibodies (Transduction laboratories, Lexington, KY, USA) and peroxidase-conjugated secondary antibodies. Immune complexes were revealed using a specific chemiluminescent detection system (Supersignal $\mathbb{R}$; Pierce, Rockford, IL, USA). Quantification was performed by scanning densitometry using a Fluor $\mathrm{S}^{\mathrm{TM}}$ imager and Quantity $\mathrm{One}^{\mathrm{TM}}$ software (Biorad, Hercules, CA, USA). Protein expression levels are given in arbitrary units (U).

\section{Measurement of systolic pulmonary artery pressure and systemic blood pressure}

Mice ( $\mathrm{n}=6$ per group) were anaesthetised via intraperitoneal injection of ketamine/xylazine $\left(100 / 10 \mu \mathrm{g} \cdot \mathrm{kg}\right.$ body weight $\left.{ }^{-1}\right)$. A Mikrotip pressure transducer (Millar, Inc., Houston, TX, USA, 1.4F) was advanced, via a PE 50 catheter inserted into the jugular vein, through the superior vena cava into the right ventricle. Right ventricular pressure was recorded by a computer data acquisition system (DI-400, Windaq; Dataq
Instruments, Akron, OH, USA). The systolic pulmonary artery pressure was assumed to be equal to the systolic right ventricular pressure. Arterial pressure was measured in awake, partially restricted, 10-14-week-old mice ( $n=6$ per group) [17].

\section{Statistical analysis}

Statistical analysis was carried out using analysis of variance for between-group comparisons and the two-tailed $\mathrm{t}$-test for single comparisons. A $\mathrm{p}<0.05$ was considered to indicate significance. Unless otherwise indicated, data are expressed as mean \pm SEM.

\section{Results}

Figure 1 shows that there was a direct relationship between vascular endothelial NO synthesis, as reflected by plasma NOx concentration, and systolic pulmonary artery pressure. The $\sim 60 \%$ lower plasma NOx concentration in eNOS-/than in control mice $(24.4 \pm 5.5$ versus $57.5 \pm 5.4 \mu \mathrm{M}, \mathrm{p}<0.001)$ was associated with a $25 \%$ increase in systolic pulmonary artery pressure $(26.5 \pm 1.1$ versus $20.9 \pm 0.6 \mathrm{mmHg}, \mathrm{p}<$ $0.001)$ and mean systemic blood pressure $(126.5 \pm 6.1$ versus $98.5 \pm 1.8 \mathrm{mmHg}, \mathrm{p}<0.01)$. In iNOS-deficient mice, plasma NOx concentration $(44.1 \pm 4.3 \mu \mathrm{M})$, pulmonary artery pressure $(22.6 \pm 1.1 \mathrm{mmHg})$ and mean systemic blood pressure $(107.8 \pm 3.9 \mathrm{mmHg})$ did not differ from that in control mice ( $>0.1)$.

In contrast to haemodynamics, vascular NO synthesis and lower respiratory tract exhaled NO were dissociated. Compared with control mice, exhaled NO concentration was augmented in the eNOS-/- mice ( $12.5 \pm 1.9$ versus $9.8 \pm 1.2 \mathrm{ppb}$, $\mathrm{p}=0.02)$, whereas it was markedly decreased in the iNOS-/mice (4.3 $\pm 1.5 \mathrm{ppb}, \mathrm{p}=0.01$ versus control mice).

To test whether the augmented lower respiratory tract NO concentration in eNOS-/- mice could be related to upregulation of another NOS isoform, the amount of iNOS and nNOS in lung homogenates was quantified. Figure 2 shows that iNOS expression was $\sim 80 \%$ greater in eNOS-/- than in control lungs. In contrast, nNOS expression was similar in eNOS-/and wild-type lungs $(20.1 \pm 6.1$ versus $21.9 \pm 4.5 \mathrm{U}, \mathrm{p}>0.1)$. To examine whether, in eNOS-/- mice, the upregulation of iNOS expression was specific to the lung, iNOS expression in liver homogenates was examined and found not to differ between eNOS-/- and wild-type mice (data not shown).

\section{Discussion}

It has been postulated that NO produced by the vascular endothelium diffuses into the alveolar space and makes up an important part of the NO exhaled from the lower respiratory tract, thereby making it a marker of endothelial function [18]. Here, this concept was directly tested and no relationship found between vascular NO synthesis and exhaled NO concentration. eNOS-/- mice with a functionally relevant impairment of vascular NO synthesis, as evidenced by decreased plasma NOx concentration and systemic and pulmonary hypertension, showed an augmented lower respiratory tract exhaled NO concentration, whereas iNOS-/- mice exhibited normal vascular NO synthesis, but exhaled $\sim 60 \%$ less NO than wild-type mice. These findings provide the first direct evidence that exhaled lower respiratory tract NO does not always provide a marker of vascular endothelial NO synthesis. Moreover, they demonstrate that iNOS is a major 

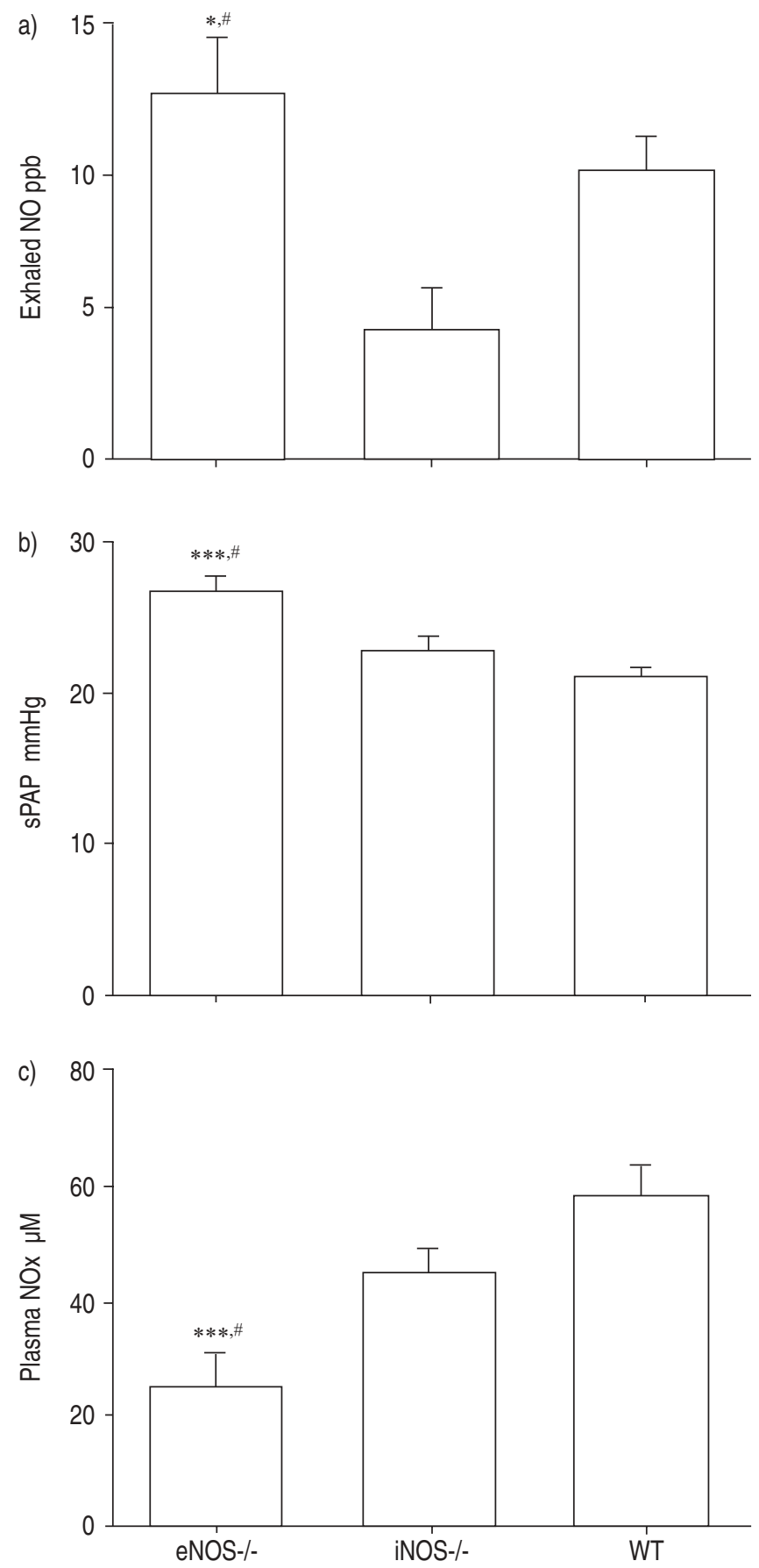

Fig. 1.-a) Lower respiratory tract exhaled nitric oxide concentration; b) systolic pulmonary artery pressure (sPAP); and c) plasma nitrite/ nitrate (NOx) concentration in endothelial nitric oxide synthase (NOS) null (eNOS-/-), inducible NOS null (iNOS-/-) and wild-type (WT) mice. Data are presented as mean \pm SEM $(n=6$ per group $(n=9$ for exhaled NO)). ppb: parts per billion. *: $\mathrm{p}<0.05$; ***: $\mathrm{p}<0.001$; versus WT; ${ }^{\#}$ : $\mathrm{p}<0.05$ versus iNOS-/-

determinant of gaseous NO production not only in the upper but also in the lower respiratory tract.

$\mathrm{NO}$ is synthesised by three different isoforms of NOS, each encoded by distinct genes. In the vascular endothelium, loss of eNOS was not functionally compensated for by the other isoforms, as evidenced by the decreased plasma NOx concentration and pulmonary and systemic hypertension in eNOS knockout mice. This defect of vascular NO synthesis, however, was not reflected in a corresponding decrease in
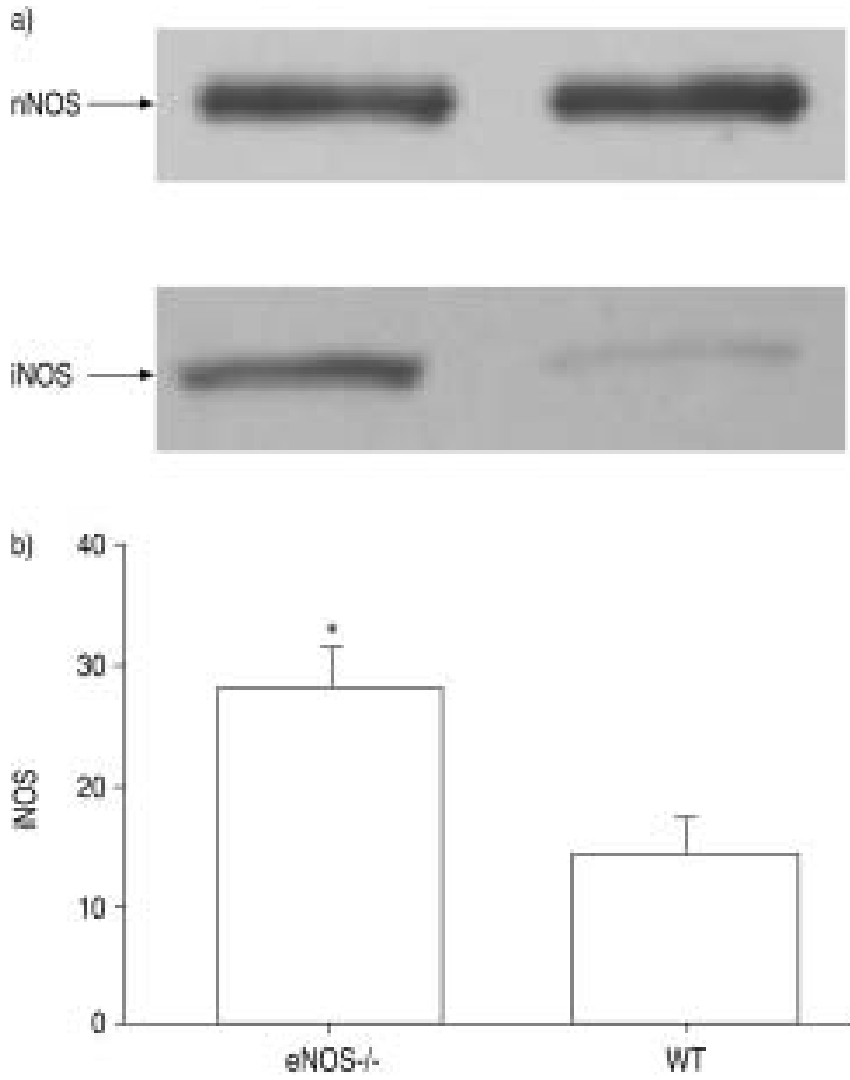

Fig. 2. - a) Western blot of lung proteins using antibodies directed against inducible nitric oxide synthase (NOS) (iNOS; $130 \mathrm{kDa}$ ) and neuronal NOS (nNOS; $155 \mathrm{kDa}$ ); and b) quantification of iNOS expression in endothelial NOS null (eNOS-/-) and wild-type (WT) mice. Data are expressed in arbitrary units and presented as mean \pm SEM ( $\mathrm{n}=9$ per group). $*$ : $\mathrm{p}<0.01$.

lower respiratory tract exhaled NO concentration. These findings indicate that, in mice, exhaled NO is not a marker of endothelial NO release, and strengthen previous indirect evidence in humans, suggesting that NO synthesised in the vasculature by eNOS does not contribute significantly to lower respiratory tract NO [13].

The relative contribution of eNOS and iNOS to lower respiratory tract NO production is not known. Endotracheal intubation in eNOS and iNOS knockout mice allowed selective assessment of the effects of these genes on this production. The present data indicate that iNOS accounts for $\sim 60 \%$ of the NO measured in exhaled air stemming from the lower respiratory tract. The remaining portion appears to be synthesised by nNOS, which has been shown to make up $\sim 40 \%$ of the NO measured in the lower respiratory tract [19].

The augmented exhaled NO concentration in eNOS-/- mice was an interesting finding. Whether or not this observation could be related to upregulation of another NOS isoform was considered. It was found that, in eNOS-/- mice, pulmonary iNOS, but not nNOS, expression was augmented. This upregulation appears not to be generalised, since hepatic iNOS expression was comparable in both strains. These findings suggest that iNOS is not only the major determinant of exhaled NO in normal mice but also accounts for the augmented pulmonary NO concentration in eNOS-/- mice.

NO synthesised in the respiratory tract may diffuse into the vasculature and regulate pulmonary vascular tone. Consistent with this hypothesis, impaired pulmonary NO synthesis in iNOS-/- mice is associated with augmented hypoxia-induced pulmonary hypertension [20], and aerosol-mediated iNOS 
gene transfer in the bronchial tree of rats attenuates hypoxic pulmonary hypertension [21]. In humans, pulmonary artery pressure is lower during nasal than during oral breathing [22], and impaired lower respiratory tract NO production is associated with exaggerated hypoxic pulmonary vasoconstriction [23]. Taken together, these data are consistent with the concept that NO derived from the respiratory tract participates in the regulation of pulmonary artery pressure. The authors speculate that, in eNOS-/- mice, augmented respiratory NO production may represent a compensatory mechanism for the loss of eNOS-derived vascular NO synthesis.

The present values obtained for lower respiratory tract exhaled NO concentration in wild-type-mice are comparable to those reported by DE SANCTIS et al. [19] using similar measurement techniques. In contrast to the present findings, in this study, exhaled NO concentration was comparable in iNOS-/- and wild-type mice using ambient air NO concentration in an airtight mouse housing chamber as an index of respiratory NO production [24]. An important limitation of this previous study, however, was that it did not allow determination of the fractional contributions of upper versus lower respiratory, and, possibly even more importantly, respiratory versus nonairway sources, to the measured NO production. It appears possible that, in this study, an augmented fractional contribution of nonairway NO to total exhaled NO may have precluded the demonstration of decreased exhaled NO concentration in iNOS knockout mice.

In conclusion, it has been shown that inducible nitric oxide synthase is a major determinant of gaseous nitric oxide production not only in the upper but also in the lower respiratory tract. Moreover, dissociation was found between vascular nitric oxide synthesis and exhaled nitric oxide concentration, indicating that lower respiratory tract exhaled nitric oxide concentration does not provide a marker of vascular endothelial nitric oxide synthesis.

Acknowledgements. The authors would like to thank C. Matthieu, K. Bouzourene, C. Anglada and L. Mazzolai for invaluable help with these studies, and to O. Hugli and C. Sartori for helpful discussions and critical review of the manuscript.

\section{References}

1. Palmer RMJ, Ferrige AG, Moncada S. Nitric oxide release accounts for the biological activity of endothelium-derived relaxing factor. Nature 1987; 327: 524-526.

2. Vallance P, Patton S, Bhagat K, et al. Direct measurement of nitric oxide in human beings. Lancet 1995; 345: 153-154.

3. Gustafson LE, Leone AM, Perrson MG, Wiklund NP, Moncada S. Endogenous nitric oxide is present in the exhaled air of rabbit, guinea pigs, and humans. Bioch Biophys Res Commun 1991; 181: 852-857.

4. Gerlach H, Rossaint R, Pappert D, Knorr M, Falke KJ. Autoinhalation of nitric oxide after endogenous synthesis in nasopharynx. Lancet 1994; 343: 518-519.

5. Lundberg JN, Weitzberg E, Nordvall SL, Kuylenstierna R, Lundberg JM, Alving K. Primarily nasal origin of exhaled nitric oxide and absence in Kartagener's syndrome. Eur Respir J 1994; 8: 1501-1504.
6. Borland C, Cox Y, Higenbottam T. Measurement of exhaled nitric oxide in man. Thorax 1993; 48: 1160-1162.

7. Sogni P, Gamier P, Gadano A, et al. Endogenous pulmonary nitric oxide production measured from exhaled air is increased in patients with severe cirrhosis. J Hepatol 1995; 23: 471-473.

8. Matsumoto A, Ogura K, Hirata Y, et al. Increased nitric oxide in the exhaled air of patients with decompensated liver cirrhosis. Ann Intern Med 1995; 123: 110-113.

9. Martin P-Y, Gines P, Schrier RW. Nitric oxide as a mediator of hemodynamic abnormalities and sodium and water retention in cirrhosis. $N$ Engl J Med 1998; 339: 533-541.

10. Bucca C, Colagrande P, Brussino L, et al. Exhaled nitric oxide in patients with mitral valve disease. Am J Respir Crit Care Med 1998; 157: A227.

11. Cailes JB, Kharitonov SA, Yates D, Barnes P, Du Bois RM. Decreased endogenous nitric oxide in the exhaled air of systemic sclerosis patients. Thorax 1995; 50: 452P.

12. Schilling J, Holzer P, Guggenbach M, Gyurech D, Marathia $\mathrm{K}$, Geroulanos S. Reduced endogenous nitric oxide in the exhaled air of smokers and hypertension. Eur Respir J 1994; 7: $467-471$.

13. Sartori C, Lepori M, Busch T, et al. Exhaled nitric oxide does not provide a marker of vascular endothelial function in healthy humans. Am J Respir Crit Care Med 1999; 160: 879-882.

14. Shesely EG, Maeda N, Kim H-S, et al. Elevated blood pressures in mice lacking endothelial nitric oxide synthase. Proc Natl Acad Sci U S A 1996; 93: 13176-13181.

15. Laubach VE, Shesely EG, Smithies O, Sherman PA. Mice lacking inducible nitric oxide synthase are not resistant to lipopolysaccharide-induced death. Proc Natl Acad Sci U S A 1995; 92: 10688-10692.

16. Yang F, Troncy E, Francoeur M, et al. Effects of reducing reagents and temperature on conversion of nitrite and nitrate to nitric oxide and detection of NO by chemiluminescence. Clin Chem 1997; 43: 657-662.

17. Duplain H, Burcelin R, Sartori C, et al. Insulin resistance, hyperlipidemia, and hypertension in mice lacking endothelial nitric oxide synthase. Circulation 2001; 104: 342-345.

18. Cremona G, Higenbottam T, Takao M, Hall L, Bower EA. Exhaled nitric oxide in isolated pig lungs. $J$ Appl Physiol 1995; 78: 59-63.

19. De Sanctis GT, Mehta S, Kobzik L, et al. Contribution of type I NOS to expired gas NO and bronchial responsiveness in mice. Am J Physiol 1997; 273: L883-L888.

20. Fagan KA, Tyler RC, Sato K, et al. Relative contributions of endothelial, inducible, and neuronal NOS to tone in the murine pulmonary circulation. Am J Physiol 1999; 277: L472-L478.

21. Janssens SP, Bloch KD, Nong Z, Gerard RD, Zoldhelyi P, Collen D. Adenoviral-mediated transfer of the human endothelial nitric oxide synthase gene reduces acute hypoxic pulmonary vasoconstriction in rats. J Clin Invest 1996; 98 : 317-324.

22. Settergren G, Angdin M, Astudillo R, et al. Decreased pulmonary vascular resistance during nasal breathing: modulation by endogenous nitric oxide from the paranasal sinuses. Acta Physiol Scand 1998; 163: 235-239.

23. Duplain H, Sartori C, Lepori M, et al. Exhaled nitric oxide in high-altitude pulmonary edema. Role in the regulation of pulmonary vascular tone and evidence for a role against inflammation. Am J Respir Crit Care Med 2000; 162: 221-224.

24. Steudel W, Kirmse M, Weimann J, Ullrich R, Hromi J, Zapol WM. Exhaled nitric oxide production by nitric oxide synthase-deficient mice. Am J Respir Crit Care Med 2000; 162: $1262-1267$. 